FOLIA HISTORICA CRACOVIENSIA, 21: 2015, s. 189-208

DOI: http://dx.doi.org/10.15633/fhc.1735

Bartłomiej Michał Wołyniec

UNIWERSYTET JAGIELLOŃSKI

\title{
Biskup Marcin Szyszkowski (1616-1630) jako twórca nabożeństwa siedmiu kościołów krakowskich
}

\section{Wstęp}

W okresie potrydenckim Kościół, starając się odpowiedzieć na duchowe potrzeby wiernych, obok starych i dobrze znanych form pobożności, propagował także nowe, odnowione spojrzenie na ich treść oraz spełniane funkcje. Jednym z podstawowych elementów, które zostały wówczas silnie związane z szeroko pojętą religijnością była niezwykle charakterystyczna dla epoki baroku teatralność. Główną rolę odgrywał w niej gest, poprzez który każdy obrzęd był przekształcany w swoistego rodzaju przedstawienie, mocno oddziałujące na umysły i serca ludzi tej epoki ${ }^{1}$. „Należało olśnić - zauważa E. E. Wróbel - by porwać masy, bardziej wszak podatne na wrażenia niż na skomplikowane argumenty" ${ }^{2}$.

Religijność baroku nie kształtowała się jednak tylko i wyłącznie jako odpowiedź na duchowe zapotrzebowania człowieka tamtych czasów, bowiem w znaczniej mierze oparta była na postanowieniach Soboru Trydenckiego. Katoliccy reformatorzy tego okresu często skupiali się na obronie tych dziedzin, które w szczególny sposób zostały zanegowane przez protestantów. Wydaje się, iż w tym przypadku Kościół w pewnym sensie samoistnie doprowadził do wzmocnienia religijności, bowiem niejednokrotnie mało istotne praktyki uczynił zasadniczymi, wyłącznie ze względu na to, że zostały one odrzucone przez zwolenników reformacji ${ }^{3}$.

Z połączenia wspomnianych powyżej dwóch źródeł potrydenckiej pobożności wykształciła się unikatowa w swoim rodzaju religijność epoki baroku. W dużej

${ }^{1}$ E. E. Wróbel, Życie religijne i zakonne w Polsce na przełomie XVI i XVII wieku, [w:] Cztery wieki Karmelitów Bosych w Polsce (1605-2005), red. A. Ruszała, Kraków 2005, s. 7.

${ }^{2}$ J. Kracik, Powszechny, apostolski, w historię wpisany, Kraków 2005, s. 263.

${ }^{3}$ E. E. Wróbel, Życie religijne..., dz. cyt., s. 8. 
mierze zamknięta do tej pory w kościelnych murach liturgia zaczęła wychodzić na ulice i place miast. Stały się one sceną nie tylko dla licznego rodzaju procesji, ale także nabożnych widowisk teatralnych oraz w jeszcze większym stopniu zsakralizowanych uroczystości państwowych. Wszystko to sprawiało, że człowiek baroku nieustannie uczestniczył $\mathrm{w}$ różnego rodzaju wydarzeniach religijnych, które z czasem stały się nieodłącznym elementem jego codziennego życia.

\section{Siedem kościołów Rzymu - Le sette chiese di Roma}

Przypuszcza się, iż opisany w XVı wieku przez św. Filipa Nereusza (1515-1595) szlak wędrówki dewocyjnej po siedmiu bazylikach Rzymu mógł mieć swoje źródła w tradycji ludowej, a bez wątpienia wynikał z przywołania i zaadaptowania do nowych warunków pamięci o znanej niegdyś ludycznej w charakterze obrzędowości modlitewnej ${ }^{4}$. Hipotezę takiego związku z wczesnośredniowieczną Modlitwa Siedmioraka sformułowała m.in. Beata Pawłowska. Badaczka przypomniała, że wspomniana modlitwa powstała za pontyfikatu papieża Grzegorza Wielkiego (590-604) i była odmawiana w intencji zakończenia szerzącej się wówczas w Rzymie epidemii dżumy. Z założenia miała w niej uczestniczyć cała - podzielona na siedem grup - społeczność miasta. Każda z nich powinna wyruszać w procesji do bazyliki Santa Maria Maggiore z jednego ze wskazanych przez papieża siedmiu rzymskich kościołów ${ }^{5}$.

Początków nabożeństwa siedmiu bazylik rzymskich można upatrywać także we wprowadzonym przez Bonifacego viII (1294-1303) w 1300 roku jubileuszu roku świętego. W bulli Antiquarum habet fida relatio papież ten ustalił, iż do uzyskania odpustu konieczne jest nawiedzenie bazylik: św. Piotra na Watykanie i św. Pawła za Murami. Zasiadający przez kolejne lata na tronie św. Piotra biskupi Rzymu uzupełniali zainicjowany przez Bonifacego viII szlak pątniczy o dalsze świątynie Wiecznego Miasta. W 1350 roku papież Klemens vi (1342-1352) stwierdził, że aby uzyskać odpust jubileuszowy, wierni winni nawiedzić także bazylikę

${ }^{4}$ O. Kwapis, Do Rzymu. Sztuka i wielkie jubileusze (1300-1575), Warszawa 2014, s. 250.

${ }^{5}$ „Zbierali się oni koło siedmiu różnych bazylik: śś. Kosmy i Damiana - kler, śś. Gerwazego i Protazego - mnisi, śś. Piotra i Marcelina - mniszki, śś. Jana i Pawła - młodzież, św. Eufemii wdowy, św. Klemensa - małżonkowie, zaś przy rotundzie św. Szczepana na Laelio - pozostali świeccy. Wędrowali oni procesyjnie do bazyliki Santa Maria Maggiore, niosąc «poparcie» świętych, by wspólnie błagać Maryję w jej bazylice” (B. Pawłowska, Urbs Sacra. Pielgrzymki i podróże religijne do Rzymu w starożytności chrześcijańskiej [IV-VII w.], Kraków 2007, s. 153). 
św. Jana na Lateranie, gdzie eksponowano relikwie cudownego oblicza Zbawiciela. Z kolei Bonifacy IX (1389-1404), który promulgował ogłoszony przez Urbana VI (1378-1389) w 1389 roku rok jubileuszowy, powiązał uzyskanie odpustu z nawiedzeniem bazyliki Santa Maria Maggiore, gdzie przechowywano relikwie żłóbka betlejemskiego. Stopniowo do pątniczego itinerarium dołączyły także tzw. trzy bazyliki mniejsze: św. Sebastiana, św. Krzyża Jerozolimskiego i św. Wawrzyńca za Murami ${ }^{6}$. Po raz pierwszy, aby uzyskać odpust jubileuszowy, pielgrzymowano do siedmiu rzymskich kościołów w trakcie jubileuszu ogłoszonego przez papieża Grzegorza XIII (1572-1585) w 1575 roku? $^{7}$.

Warto wspomnieć, iż o istnieniu szlaku pielgrzymkowego Le sette chiese di Roma, jako nabożeństwie zaaprobowanym przez władze kościelne, wspominają dwa średniowieczne przewodniki po Wiecznym Mieście: Descriptio plenaria totus urbis oraz jego wersja rozszerzona Graphia aurea urbis Romae. W obu dziełach przedstawiony został konieczny do uzyskania odpustu program nawiedzenia wspomnianych powyżej siedmiu rzymskich bazylik ${ }^{8}$.

Okazało się jednak, że nabożeństwo było w głównej mierze odprawiane przez mieszkańców Rzymu oraz pątników z Italii. Większość wiernych nie miała bowiem możliwość dotarcia do miasta i uzyskania związanych z pielgrzymką odpustów. Z tego też powodu kolejni papieże nadawali różnym świątyniom w całej Europie przywileje odprawiania omawianego nabożeństwa. Dla przykładu warto podać, iż w 1484 lub 1487 roku Innocenty viII (1484-1492) udzielił takiego prawa dominikankom $z$ augsburskiego konwentu św. Katarzyny ${ }^{9}$. Oznaczało to, że pątnicy, którzy przybywali do tego klasztoru, otrzymywali odpust równy indulgencji należnej za fakt podróży do Wiecznego Miasta i nawiedzenia siedmiu rzymskich bazylik $^{10}$.

${ }^{6}$ J. Smolucha, S. A. Sroka, Historia lat świętych, Kraków 200o, s. 18, 22, 26.

7 E. M. Jung-Inglessis, Rok Święty w Rzymie. Historia i teraźniejszość, Warszawa 200o, s. 161.

${ }^{8}$ J. Chélini, H. Branthomme, Drogi Boże. Historia pielgrzymek chrześcijańskich, Warszawa 1996, s. 120. Por. J. Kalinowska, Mysterium Septiformis Ecclesaie, „Annalecta Cracoviensia” 23 (1991), s. 307-323.

${ }^{9}$ S. Eiche, Le Basiliche e il loro doppio: le sei tavole di Augsburg, [w:] Roma Sancta. La città delle basiliche, a cura di M. Fagiolo, M. L. Madonna, Roma 1985, s. 47; O. Kwapis, Do Rzymu..., dz. cyt., s. 253. Por. M. Schawe, Rom in Augsburg. Die Basilikabilder aus dem Katharinenkloster, München 2000; G. Goldberg, Zum Zyklus de Augsburger Basilikabilder und zur Existenz von Stellvertreterstätten römische Hauptkirchen, „Bayerisches Jarbuch für Volkskunde“ 1986/87, s. 65-75.

${ }^{10}$ O. Kwapis, Do Rzymu..., dz. cyt., s. 253. Uzyskany przez augsburski klasztor dominikanek przywilej nie był niczym nadzwyczajnym w ówczesnej Europie. Z podobnymi zabiegami spotkać się możemy - na nieco większą skalę - także w okresie potrydenckim, kiedy nabożeństwo siedmiu kościołów rzymskich przeżywało swój renesans. W tym czasie odpowiednie przywileje odpustowe 
W okresie trydenckiej odnowy Kościoła pielgrzymkę do siedmiu rzymskich bazylik w sposób szczególny zalecał wiernym św. Filip Nereusz. Podstawowe znaczenie dla odnowienia tego pątniczego szlaku miała w jego przekonaniu pamięć o starożytnościach chrześcijańskich oraz oprowadzanie pielgrzymów po miejscach, które w sposób szczególny były z chrześcijaństwem związane. Jednym z pątników, który wspólnie ze św. Filipem Nereuszem wyruszył w 1563 roku szlakiem siedmiu kościołów Wiecznego Miasta, był św. Karol Boromeusz (1538-1584). Od tej pory także on propagował ten sposób nawiedzania rzymskich bazylik i szlak siedmiu kościołów zalecał wszystkim przybywającym do Rzymu pielgrzymom ${ }^{11}$.

Itinerarium opisane przez św. Filipa Nereusza wyznaczały wspomniane powyżej cztery bazyliki większe: św. Piotra na Watykanie, św. Pawła za Murami, św. Jana na Lateranie, Najświętszej Maryi Panny Śnieżnej oraz trzy mniejsze: św. Krzyża Jerozolimskiego, św. Wawrzyńca za Murami oraz św. Sebastiana ${ }^{12}$. Ustalony przez niego porządek nawiedzania poszczególnych świątyń potwierdza chronologia opisu przyjęta przez Giovanniego Severano w opublikowanym w 1630 roku dziele Memorie sacre delle sette chiese di Roma e di altri luoghi, che si trovano per le strade di esse ${ }^{13}$, które $\mathrm{w} 1654$ roku zostało wydane pod zmienionym tytulem: Divotioni da prattica nelle visita delle sette Chiese di Roma ${ }^{14}$. Rekonstruując potrydencką wędrówkę tym szlakiem, sięgnąć można także po pochodzącą z XVII wieku mapę, która została zatytułowana Dispositione e strada delle sette chiese. Wedle jej wskazań porządek pielgrzymki był następujący: wędrówkę rozpoczynano od bazyliki św. Piotra na Watykanie, aby następnie przez Trastavere, Isola

uzyskali m.in. św. Karol Boromeusz dla Mediolanu oraz miejscowość Monselice, gdzie powstało sanktuarium pielgrzymkowe. Monselice nel cuore del Giubileo. Guida del pellegrino al Santuario Giubilare delle sette Chiese in Monselice, Monselice 1999; M. Vazzoler, Il giubileo di San Carlo Borromeo (Milano, 1576), Milano 1999, s. 52-56. Por. B. Krasnowolski, Zapomniane sanktuarium maryjne i lateraneńskie z I poł. XVII wieku w Suchej: wielka treść w skromnej formie, [w:] Festina lente. Prace ofiarowane Andrzejowi Fischingerowi w siedemdziesiąta rocznicę urodzin, Kraków 1998, s. 131-132.

${ }^{11}$ L. Fiorani, Le confraternite, la città e la „perdonanza giubilare”, [w:] Roma Sancta. La città delle basiliche, a cura di M. Fagiolo, M. L. Madonna, Roma 1985, s. 65; R. Delcroix, Filippo Neri. Il Santo dell’allegria, Milano 2011, s. 118-130. Por. A. Stróż, Historia badań nad zagadnieniem najstarszych zachodnich sanktuariów męczenników. Od kontrreformacyjnej apologetyki do wspótczesnych badań interdyscyplinarnych, „Vox Patrum” 33 (2013), s. 317-319.

${ }^{12}$ O. Kwapis, Do Rzymu..., dz. cyt., s. 251.

${ }^{13}$ G. Severano, Memorie sacre delle sette chiese di Roma e di altri luoghi, che si trovano per le strade di esse, Roma 1630.

${ }^{14}$ Tenże, Divotioni da prattica nelle visita delle sette Chiese di Roma, Roma 1654. 
Tiberina oraz Porta San Paolo dotrzeć do bazyliki św. Pawła. Stamtąd wzdłuż murów aureliańskich dojść do bazyliki św. Sebastiana, skąd dalsza droga wiodła przez Porta San Sebastiano do bazyliki św. Jana na Lateranie. Kolejno należało udać się do bazyliki św. Krzyża Jerozolimskiego, skąd ponownie poza murami miejskimi przez Porta Maggiore dochodziło się do bazyliki św. Wawrzyńca. Ostatnia faza wędrówki obejmowała przejście przez Porta San Lorenzo i zakończenie pielgrzymki w bazylice Santa Maria Maggiore ${ }^{15}$.

Warto wspomnieć, iż tradycja wędrowania do siedmiu bazylik rzymskich była bezpośrednią inspiracją dla Antonia Lafréry’ego, autora ryciny Le Sette Chiese di Roma, która została wykonana z okazji Roku Świętego ogłoszonego w 1575 roku przez papieża Grzegorza XıII ${ }^{16}$. Grafika wyobraża wspominane rzymskie bazyliki oraz łączące je drogi, które wypełnione są zwartym szeregiem pielgrzymów. Wyodrębnione grupy pątników, proporcjonalnie większych w stosunku do innych przedstawionych w grafice wiernych, ukazano przed frontonami czterech bazylik większych. Modlą się oni, klęcząc u stóp świętych patronów poszczególnych bazylik. Święci - co warto podkreślić - zostali przedstawieni pod postaciami żywych osób, które witają przybyłych do poświęconych ich imieniu kościołów. Gestem powitania zapraszają do nawiedzenia świątyń patroni czterech bazylik większych: Najświętsza Maryja Panna oraz święci Piotr, Paweł i Jan ${ }^{17}$.

Wspomnianą rycinę, jak i wydaną w tym samym czasie grafikę Roma Sancta dedykowaną kard. Stanisławowi Hozjuszowi (1504-1579), można uznać za świadectwo realizacji programu ikonograficznego służącego bezpośredniemu oddziaływaniu na wiernych, którzy wraz z podjęciem pątniczej wędrówki stawać się mieli uczestnikami nie tylko wspólnotowego przeżycia duchowego, lecz także procesu umacniania wiary i siły Kościoła realizowanego zgodnie z zaleceniami

${ }^{15}$ R. Bernabei, Roma nel giubileo, Milano 1998, s. 65; O. Kwapis, Do Rzymu..., dz. cyt., s. 270.

${ }^{16}$ Barock im Vatikan. Kunst und Kultur im Rom der Päpste, vol. 2: 1572-1676, Hrsg. J. Frings, Leipzig 2005, s. 192; O. Kwapis, Do Rzymu..., dz. cyt., s. 267-269. Por. C. Hülsen, Das Speculum Romanae Magnificentiae des Antonio Lafreri, [w:] Colloctanaea variae doctrinae, München 1921, s. 121-170; J. Garms, Vedute di Roma. Dal Medioevo all'Ottocento. Atlante iconografico, topografico, architettonico, vol. 1-2, Napoli 1995; H. Gamrath, Roma Sancta Renovata. Studi sullurbanistica di Roma nella seconda metà del sec. XVI con particolare riferimento al pontificato di Sisto V (15851590), Roma 1987; K. Zeitler, Wege durch Rom. Druckgraphische Veduten aus drei Jahrhunderten, München 1999.

${ }^{17}$ O. Kwapis, Do Rzymu..., dz. cyt., s. 267-269. Por. S. Prosperi Valenti Rodinò, L'immagine degli anni santi nelle stampe, [w:] La storia dei Giubilei, vol. 2: 1450-1575, a cura di M. Fagiolo, M. L. Madonna, Milano 1998, s. 286; A. Rinaldi, Le sette meraviglie della Roma cristiana. L'invenzione del Lafréry, [w:] Roma Sancta. La città delle basiliche, a cura di M. Fagiolo, M. L. Madonna, Roma 1985, s. 269-271. 
dekretów Soboru Trydenckiego. Zadanie to wypełniano, przemierzając drogę siedmiu kościołów, która przeobrażała Rzym w ogromną scenę liturgii papieskiej. Jej poszczególnymi stacjami były kolejne bazyliki. W ten sposób przywrócono istniejąca już w czasach przedawiniońskich tradycję celebrowania nabożeństw papieskich na terenie całego miasta. Zwyczaj ten zanikł bowiem po powrocie papieży z tzw. niewoli awiniońskiej, od kiedy pozostawali oni w obrębie bazyliki św. Piotra ${ }^{18}$.

\section{Siedem kościołów Krakowa - Le sette chiese di Cracovia}

W 1621 roku w krakowskiej oficynie drukarskiej Franciszka Cezarego została wydana broszura zatytułowana Siedm kościołów krakowskich. W jej podtytule czytamy, iż jest to „Informacya o początku nabożeństwa obchodzenia Siedmi Kościołów tak w Rzymie, iako y w Krakowie y o sposobie iakim toż nabożeństwo w tym tu Mieście odprawowane być ma" ${ }^{19}$. Jej druk został podjęty na wyraźne polecenie biskupa krakowskiego Marcina Szyszkowskiego (1616-1630), „na którego usilną prośbę, ten tak wielki Przywilej Miastu temu iest pozwolony"

Wydaje się, iż główną przyczyną powstania pątniczego szlaku siedmiu kościołów Krakowa było zagrożenie tureckie oraz najazdy tatarskie, które co pewien czas nękały Rzeczypospolitą. Autor omawianej broszury zauważył bowiem, iż istnieje „zwyczaj Kościoła Ś. Katolickiego we wszelkich pospolitych niebezpieczeństwach na część iaką Chrześcijaństwa następuiących, [...] lud [...] do skruchy za grzechy y pokuty pobudzając y nabożne nawiedzania kościołów niektórych do tego naznaczaiąc”21. Z tego też powodu M. Szyszkowski zdecydował, „widząc [...] gwałtowne prawie potrzeby y wielkie niebespieczenstwa Korony tey, iść tymże

${ }^{18}$ O. Kwapis, Do Rzymu..., dz. cyt., s. 269.

${ }_{19}$ Siedm kościołów krakowskich. Od Stolice Apostolskiey pozwoleniem Odpustów Siedmi Kościołów Miasta Rzymskiego uprzywilejowanych [...], Kraków 1621. W 2006 roku został opublikowany artykuł Z. Bani, który dotyczy nabożeństwa Siedmiu kościołów Krakowa, ale czyni to bardzo pobieżnie: Z. Bania, Kraków - Rzymem Rzeczypospolitej w pierwszej połowie XVII wieku, [w:] Praxis atque theoria. Studia ofiarowane profesorowi Adamowi Małkiewiczowi, red. W. Bałus, J. K. Ostrowski, Kraków 2006, s. 25-33.

${ }^{20}$ Siedm kościołów krakowskich..., k. A1r. Por. Kleynoty Stołecznego Miasta Krakowa [...], Kraków 1650, s. 94: „Marcin Szyszkowski, stacye siedmiom Kościołom Krakowskim z Odpustami co y w Rzymie przy Kościołach siedmi są, wyprawił”.

${ }^{21}$ Siedm kościołów krakowskich..., k. A5r-v. 
trybem Kościoła powszechnego"22. Hierarcha wystosował zatem odpowiednie listy do papieża Pawła v (1605-1621), w których prosił, aby ten zezwolił na odprawianie w Krakowie nabożeństwa siedmiu kościołów rzymskich i dostąpienia przez uczestniczących w nim wiernych wszystkich tych odpustów, jakie mogą uzyskać ci pielgrzymujący do siedmiu rzymskich bazylik ${ }^{23}$. Autor omawianej broszury wspomina, iż papież nie od razu uczynił zadość prośbom krakowskiego ordynariusza. Niemniej jednak „za powtarzanymi y gorącemi [jego] prośbami [...] na siedm lat łaskę tę wielką Miastu temu uczynił"24.

Odpowiedni dokument Paweł v wydał w dniu 11 czerwca 1620 roku i stwierdził w nim, że przychylił się do prośby biskupa: „ad augendam fidelium religionem et animarum salutem", tj. dla zwiększenia wiary i zbawienia dusz ${ }^{25}$. Papież zastrzegł jednak, iż odprawiający to nabożeństwo wierni dostąpią odpuszczenia grzechów i wszelkich związanych z tą pielgrzymką odpustów, jeżeli w każdym z siedmiu kościołów modlić się będą we wskazanych przez niego intencjach: o zgodę między książętami chrześcijańskimi, o wyplenienie herezji oraz o wywyższenie Kościoła Katolickiego ${ }^{26}$.

Otrzymawszy papieską zgodę M. Szyszkowski skierował do duchowieństwa diecezji krakowskiej list pasterski, który został im odczytany podczas zwołanego do Krakowa w początku 1621 roku synodu diecezjalnego. Tam też powzięte zostały pierwsze postanowienia co do charakteru krakowskiego nabożeństwa. Zredagowana instrukcja mówiąca o sposobie odprawiania omawianej pielgrzymki została włączona do wydanych drukiem postanowień synodalnych,

${ }^{22}$ Siedm kościołów krakowskich..., k. A5v.

${ }^{23}$ Siedm kościołów krakowskich..., k. A5v-A6r.

${ }^{24}$ Siedm kościołów krakowskich..., k. A6r. Nabożeństwo to przetrwało w Krakowie jednak o wiele dłużej, o co zabiegali kolejni biskupi krakowscy. W związku z wygaśnięciem papieskiego przywileju, w 1626 roku M. Szyszkowski wystarał się o nowy papieski dokument. Papież Urban VIII (1623-1644) w breve z 8 lipca 1626 roku zezwolił na odprawianie nabożeństwa przez kolejnych dwanaście lat, a więc do 1638 roku (Archiwum Krakowskiej Kurii Metropolitalnej, A. Ep. 43, k. 608v-609). Kolejnym biskupem krakowskim zainteresowanym nabożeństwem Siedmiu kościołów krakowskich był Andrzej Trzebicki (1658-1679), który wyjednał przywilej tego nabożeństwa u papieża Aleksandra VII (1655-1667) w 1661 roku (Siedm kościołów krakowskich..., wyd. 1661). O popularności tego pątniczego szlaku, jak i jego obecności w religijnej kulturze Krakowa świadczy także zamieszczenie informacji o nabożeństwie i sposobie jego odprawiania w dziele Kleynoty Stołecznego Miasta Krakowa wydanym w 1650 roku oraz 1745 roku (Kleynoty..., wyd. 1650, s. 95-97; Kleynoty..., wyd. 1745, s. 125-126).

${ }^{25}$ Instructio ad visitandas Septem Ecclesias Cracoviae [...], [w:] Reformationes Generales [...], Cracovia 1621, k. 154.

${ }^{26}$ Instructio ad visitandas Septem Ecclesias Cracoviae..., k. 154. 
które ukazały się w samym roku pod tytułem Reformationes Generales. Warto zaznaczyć, iż umieszczenie Instructio ad visitandas Septem Ecclesias Cracoviae w statutach synodalnych miało na celu szerokie rozpropagowanie nabożeństwa wśród duchowieństwa i wiernych diecezji krakowskiej, bowiem - zgodnie z założeniem biskupa - miały one trafić do każdej parafii diecezji, których w tym okresie było blisko tysiąc.

Temu samemu miało służyć wydanie w 1620 i 1621 roku dwóch broszur, które podawały sposób odprawiania nabożeństwa siedmiu kościołów krakowskich. Pierwszą z nich był druk zatytułowany Instructio ad Visitandas Septem Ecclesias Cracoviae wydany w 1620 roku, a drugim Siedm kościołów krakowskich wydane rok później. Pierwszy z nich skierowany był przede wszystkim do duchowieństwa i ludzi wykształconych, którzy bez trudu posługiwali się łaciną ${ }^{27}$. Większość wiernych mogła natomiast korzystać z wydanego w 1621 roku druku Siedm kościołow krakowskich, który w sposób przystępny dla przeciętnego - ale umiejącego - czytać mieszkańca diecezji krakowskiej opisywał poszczególne etapy omawianego nabożeństwa. Warto zauważyć, iż broszura ta zachowała się do naszych czasów w niewielu egzemplarzach, co może świadczyć nie tylko o niezwykłej popularności samego nabożeństwa, ale także jej „zaczytaniu” przez wiernych. Broszura była bowiem przewodnikiem o znamionach modlitewnika, który oprócz sposobu odprawiania nabożeństwa podawał także proponowane wiernym modlitwy i rozważania.

Pierwsze nabożeństwo siedmiu kościołów krakowskich odbyło się 14 lutego 1621 roku w tzw. niedzielę mięsopustną, czyli przedostatnią niedzielę karnawału. Wówczas to M. Szyszkowski „przy wielkiej liczbie duchowieństwa Biskupstwa Krakowskiego na Synod od niego pod ten czas nakazany zgromadzonego, szczęśliwie do skutku to pozwolenie Stolice Apostolskiey przywiódł" ${ }^{28}$. Rozpoczęło się ono w katedrze wawelskiej, gdzie hierarcha celebrował mszę o Duchu Świętym, po której zakończeniu nakazał odczytać przywilej papieża Pawła v, w którym ten zezwolił na odprawienie tego rzymskiego nabożeństwa w Krakowie. Biskup zgodnie z treścią papieskiego dokumentu - sam wyznaczył siedem kościołów stacyjnych oraz znajdujące się w nich ołtarze uprzywilejowane. Następnie wraz "ze wszytkiem duchowieństwem tak świeckim iako zakonnym y z bractwy” udał się procesjonalnie do wyznaczonych przez siebie świątyń stacyjnych, gdzie

\footnotetext{
${ }^{27}$ Instructio ad Visitandas Septem Ecclesias Cracoviae [...], Cracovia 1620.

${ }^{28}$ Siedm kościołów krakowskich..., k. A6r-v. Warto zaznaczyć, iż nabożeństwo, któremu przewodniczył hierarcha, miało charakter uroczysty i w zasadniczy sposób różniło się od sposobu jego odprawiania zalecanego dewocji indywidualnej.
} 
wyznaczeni uprzednio kapłani głosili kazania ${ }^{29}$. Ostatni z przywołanych elementów nabożeństwa należy ze wszech miar podkreślić, bowiem autor cytowanej broszury wspomina jedynie o kazaniu, które zostało wygłoszone w jezuickim kościele świętych Piotra i Pawła. Dotyczyło ono początków, przyczyn i sposobu odprawiania nabożeństwa i „z rozkazania iego [Marcina Szyszkowskiego] miane było" ${ }^{30}$.

W przygotowanej do szerokiego rozpowszechnienia wśród wiernych broszurze Siedm kościołów krakowskich biskup wymienił pięć warunków, których wypełnienie było podstawą do uzyskania odpustów w trakcie odprawianego przez wiernych nabożeństwa.

Pierwszym z nich było trwanie w stanie łaski uświęcającej, bowiem każdy „przetoż, który się czuie być w grzechu śmiertelnym powinien abo się wyspowiadać abo przez prawdziwą skruchę y żal za grzechy [...] z Panem Bogiem się poiednać" ${ }^{11}$. Każdy kto chce dostąpić przypisanych odpustów powinien uczestniczyć w nabożeństwie z własnej woli i „mieć ten umysł y intencję dostąpić tych odpustów”. Hierarcha zaznaczył jednak, iż „nie potrzeba [...] na ten się umysł $\mathrm{y}$ wolę zdobywać $\mathrm{y}$ te intencję $\mathrm{w}$ sobie wzbudzać $\mathrm{w}$ każdym $\mathrm{z}$ osobna $\mathrm{z}$ tych siedmi Kościołów, ale dosyć mieć go abo na weszciu na to nabożeństwo abo w wybieraniu się y przygotowaniu do niego abo przy samym zaczęciu”. Odpustu nie dostąpi natomiast ten, który „iedno dla przechadzki abo rekreacyey swey abo rozmowy y dobrey kompaniey z drugiemi y obaczenia co się tam dzieie Kościoły [będzie] nawiedzał" 32 .

Drugim wymogiem stawianym udającym się na peregrynację wiernym było nawiedzenie wszystkich siedmiu wyznaczonych przez Marcina Szyszkowskiego kościołów. W ich liczbie zawierała się katedra wawelska, kościół świętych Piotra i Pawła, kościoły dominikanów, franciszkanów i bernardynów, kolegiata akademicka św. Anny oraz kościół farny Najświętszej Maryi Panny. Biskup zaznaczył ponadto, że nawiedzenie wszystkich tych kościołów winno odbyć się w jeden dzień. Wskazał przy tym, że „wolno jedne rano, drugie po południu, bądź przed wzięciem pokarmu, bądź po obiedzie odprawować”. Do dyspozycji wiernych pozostawił także sposób przemieszczania się pomiędzy poszczególnymi świątyniami. Wierni mogli to czynić „bądź na wozie, bądź na koniu, bądź pieszo". Ta ostatnia forma wydawała się biskupowi najlepszym sposobem

\footnotetext{
${ }^{29}$ Siedm kościołów krakowskich..., k. A6v.

${ }^{30}$ Siedm kościołów krakowskich..., k. B5v.

${ }^{31}$ Siedm kościołów krakowskich..., k. A7r-v.

${ }^{32}$ Siedm kościołów krakowskich..., k. A7v.
} 
pielgrzymowania i każdy, „któremu zdrowie dopuszcza” w taki właśnie sposób winien odprawiać to nabożeństwo ${ }^{33}$.

Trzeci warunek określony przez hierarchę powiązany został z poprzednim i dotyczył miejsca odprawianej przez wiernych modlitwy. Wskazane bowiem było, aby czynili to przy ołtarzach naznaczonych przez biskupa, czyli tzw. ołtarzach uprzywilejowanych. Dla łatwości ich odnalezienia, przy każdym z nich umieszczona była tablica $\mathrm{z}$ napisem, iż jest to ołtarz, przy którym można uzyskać odpusty związane z nabożeństwem tzw. siedmiu kościołów. Podobnie jak w przypadku nawiedzania poszczególnych świątyń, tak i w przypadku modlitwy przy poszczególnych ołtarzach biskup pozostawił wiernym wybór kolejności ich nawiedzania. Ponadto zostało zaznaczone, iż pątnicy nie muszą znajdować się bezpośrednio przed ołtarzem, aby pomodlić się w wyznaczonych intencjach, „bo dosyć uczyni tey powinności, gdy z daleka, widząc iednak one, przed każdym z osobna [...] Panu Bogu będzie modlitwy swoie ofiarował”. Woli każdego pielgrzyma za zgodą Ojca Świętego hierarcha zostawił także wybór modlitw, „które się czynić maią przed ołtarzami naznaczonemi”. Hierarcha dopuścił, aby wierni modlili się „bądź usty, bądź sercem”. Zgodnie z zasadami przedstawionymi w omawianej broszurze, „wolno mówić u każdego Ołtarza abo trzy Pacierze y trzy Zdrowe Marye, abo pięć Pacierzy y pięć Zdrowych Mariy abo siedm”. Można odmawiać także część różańca albo koronki do NMP, bądź też dowolnie wybraną litanię lub jedną z godzinek: o NMP, o Krzyżu Świętym lub Duchu Świętym. Kolejną możliwością była modlitwa psalmem oraz jakakolwiek inna modlitwa, której wyboru dokona poszczególny pielgrzym. Najważniejsze było bowiem, aby każdy z wiernych stojąc przy wspomnianych ołtarzach, zanosił swoje modlitwy w trzech wyżej przywołanych intencjach, które są intencjami wyznaczonymi przez Ojca Świętego ${ }^{34}$.

Kościół katedralny świętych Wacława i Stanisława otrzymał przywileje i odpusty bazyliki św. Jana na Lateranie, a biskup Szyszkowski wyznaczył w nim trzy ołtarze uprzywilejowane. Pierwszym z nich był ołtarz Najświętszego Sakramentu w kaplicy króla Stefana Batorego, drugim ołtarz przy grobie św. Stanisława, a trzecim ołtarz św. Krzyża przy katedralnej zakrystii ${ }^{35}$.

Kościół świętych Piotra i Pawła otrzymał odpusty bazyliki św. Piotra na Watykanie i zostało w nim wyznaczonych aż siedem ołtarzy stacyjnych. Pierwszym z nich był ołtarz wielki, drugim ołtarz Pana Jezusa w krzyżu kościoła, a trzecim

\footnotetext{
${ }^{33}$ Siedm kościołów krakowskich..., k. A7v-A8v.

${ }^{34}$ Siedm kościołów krakowskich..., k. A8v-B3r.

${ }^{35}$ Siedm kościołów krakowskich..., k. Bir.
} 
ołtarz NMP umieszczony naprzeciw poprzedniego. Czwartym ołtarzem wyznaczonym przez biskupa był ołtarz Trójcy Świętej i Nawrócenia św. Pawła, piątym ołtarz Aniołów Stróżów, szóstym natomiast ołtarz świętych Zygmunta i Kazimierza. Ostatnim siódmym ołtarzem był ołtarz świętych Grzegorza Wielkiego i Karola Boromeusza ${ }^{36}$. Ostatni z ołtarzy nie został wspomniany w Kleynotach wydanych w 1650 roku $\mathrm{W}$ tym samym jednak dziele ołtarz poświęcony św. Zygmuntowi i św. Kazimierzowi stanowi dwa oddzielne obiekty kultu ${ }^{37}$. Warto ponadto zwrócić uwagę, że ołtarze wyznaczone pierwotnie praktycznie w całości nie były tożsame z tymi, które posiadały odpusty w połowie XvIII wieku. Zgodnie z informacjami zawartymi w Kleynotach wydanych w 1745 roku w kościele jezuitów wśród ołtarzy uprzywilejowanych znajdowały się: ołtarz wielki oraz ołtarze Niepokalanego Poczęcia NMP, św. Stanisława Kostki, św. Franciszka Ksawerego, św. Michała Archanioła, św. Ignacego Loyoli i Pana Jezusa Ukrzyżowanego ${ }^{38}$.

Kolejna ze świątyń stacyjnych, czyli dominikański kościół Świętej Trójcy otrzymał przywileje odpustowe bazyliki św. Pawła za Murami. Biskup M. Szyszkowski wyznaczył w nim, tak jak w poprzedniej świątyni, siedem ołtarzy uprzywilejowanych. Pierwszym był ołtarz wielki, drugim ołtarz NMP w kaplicy różańcowej, trzecim natomiast ołtarz przy grobie św. Jacka. Czwarty z ołtarzy poświęcony Krzyżowi Świętemu znajdował się w kaplicy położonej obok schodów prowadzących do kaplicy św. Jacka. Piąty pod wezwaniem św. Katarzyny Sieneńskiej znajdował się w kaplicy Zbaraskich, szósty w kaplicy Lubomirskich, a siódmy w kaplicy Myszkowskich ${ }^{39}$. Autor Kleynotów z 1650 roku podaje, iż jeden z ołtarzy uprzywilejowanych nosił co prawda wezwanie św. Katarzyny Sieneńskiej, ale związane $\mathrm{z}$ nim odpusty zostały przeniesione do kaplicy św. Wincentego ${ }^{40}$. Z kolei wydanie tegoż dzieła z 1745 roku informuje, że dwa ołtarze uprzywilejowane znajdowały się $\mathrm{w}$ kaplicy różańcowej: pierwszym $\mathrm{z}$ nich był ołtarz poświęcony NMP, drugi był natomiast dedykowany św. Wincentemu ${ }^{41}$. W tym samym czasie przeniesieniu uległ także ołtarz poświęcony Krzyżowi Świętemu. Zgodnie

${ }^{36}$ Siedm kościołów krakowskich..., k. Bır-v. Warto w tym miejscu wspomnieć, iż ołtarze, które istniały w czasach biskupa M. Szyszkowskiego, albo do naszych czasów się nie zachowały, albo też zmieniły patrocinium. Omawiana broszura może dzięki temu stanowić także źródło do dziejów poszczególnych kościołów i zachodzących w nich przemian, ale również przede wszystkim kultu świętych w potrydenckim Krakowie.

${ }^{37}$ Kleynoty..., wyd. 165o, s. 96.

${ }^{38}$ Kleynoty..., wyd. 1745, s. 126.

${ }^{39}$ Siedm kościołów krakowskich..., k. B1v. Kleynoty..., wyd. 1650, s. 50.

${ }^{40}$ Kleynoty..., wyd. 1650, s. 96.

${ }^{41}$ Kleynoty..., wyd. 1745, s. 125. 
z informacjami zaczerpniętymi z wydanych w 1745 roku Kleynotów znajdował się on na krużganku, a nie jak było to pierwotnie w kaplicy przy schodach wiodących do kaplicy św. Jacka ${ }^{42}$.

Kościół św. Bernardyna oo. bernardynów na Stradomiu otrzymał odpusty bazyliki św. Sebastiana i zostało w nim wyznaczonych pięć ołtarzy uprzywilejowanych. Pierwszym był ołtarz NMP „nabożeństwem ludzi pobożnych znaczny”, drugim ołtarz Wieczerzy Pańskiej, trzecim natomiast ołtarz św. Franciszka przy grobie św. Szymona z Lipnicy. Czwarty ołtarz uprzywilejowany dedykowany był św. Bernardynowi, a piąty św. Annie ${ }^{43}$.

Kolegiata akademicka św. Anny otrzymała odpusty bazyliki św. Krzyża Jerozolimskiego. Biskup M. Szyszkowski wyznaczył w niej trzy ołtarze uprzywilejowane: ołtarz wielki, ołtarz Najświętszego Sakramentu oraz ołtarz NMP przy grobie bł. Jana Kantego ${ }^{44}$. Zgodnie z treścią Kleynotów wydanych w 1745 roku ołtarz Najświętszego Sakramentu został w bliżej nieokreślonym momencie zastąpiony przez ołtarz Zdjęcia Pana Jezusa z Krzyża ${ }^{45}$.

Świątynia oo. franciszkanów pw. św. Franciszka otrzymała przywileje odpustowe bazyliki św. Wawrzyńca i znajdowało się w niej siedem ołtarzy uprzywilejowanych. Pierwszym był ołtarz wielki, drugim ołtarz św. Antoniego z Padwy, trzecim natomiast ołtarz NMP przy grobie bł. Salomei. Czwarty ołtarz usytuowany był w kaplicy Arcybractwa Męki Pańskiej, a piąty nosił wezwanie św. Krzyża. Szósty z ołtarzy znajdował się w kaplicy Matki Bożej na krużganku, gdzie usytuowany był także ołtarz siódmy dedykowany Miłosierdziu Bożemu ${ }^{46}$.

Kościół farny NMP otrzymał przywileje bazyliki NMP Większej i zostały w nim wyznaczone trzy ołtarze uprzywilejowane: ołtarz wielki, ołtarz Najświętszego Sakramentu oraz ołtarz NMP zwany Loret ${ }^{47}$. Ich liczba wzrosła w połowie XVIII wieku, jak informują bowiem Kleynoty wydane w 1745 roku do trzech poprzednich dołączyły także ołtarze: Pana Jezusa Ukrzyżowanego, Zwiastowania NMP, św. Sebastiana oraz Trzech Króli ${ }^{48}$.

Jak było to już wspomniane, w trakcie nawiedzania siedmiu kościołów krakowskich wierni byli zobowiązani jedynie do modlitwy w trzech wyrażonych przez papieża Pawła v intencjach. Biskup M. Szyszkowski w wydanych drukiem

\footnotetext{
${ }^{42}$ Kleynoty..., s. 126.

${ }^{43}$ Siedm kościołów krakowskich..., k. B2r-v; Kleynoty..., wyd. 1650, s. 96.

${ }^{44}$ Siedm kościołów krakowskich..., k. B2r.

${ }^{45}$ Kleynoty..., wyd. 1745, s. 125.

${ }^{46}$ Siedm kościołów krakowskich..., k. B2r.

47 Siedm kościołów krakowskich..., k. B2r.

${ }^{48}$ Kleynoty..., wyd. 1745, s. 126.
} 
instrukcjach nie wyznaczył konkretnych modlitw, które winni oni odmawiać i ich dobór pozostawił osobistemu wyborowi każdego pielgrzyma. Wydaje się jednak, że w nawiązaniu do rozważań ułożonych przez św. Filipa Nereusza dla rzymskiego szlaku pątniczego ${ }^{49}$, hierarcha zalecał, aby także w trakcie obchodzenia siedmiu kościołów Krakowa wierni rozważali tajemnice Męki Pańskiej. „Naypożytecznieysze iest [bowiem] na przygotowanie nasze do dostąpienia Odpustów [...] Męki Pańskiej rozmyślanie"50. Autor broszury Siedm kościołów krakowskich argumentuje, iż dokonany przez hierarchę dobór tematyki rozważań ma swoje uzasadnienie w nauczaniu św. Alberta Wielkiego. Twierdził on bowiem, że „więcey iest pożyteczne do oczyścienia sumienia y powstania z grzechów y do pożytku duchownego y wzniecenia w sercach ludzkich wszelkiego nabożeństwa iedno samo Męki Pańskiej z uważaniem rozmyślanie" ${ }^{51}$.W związku z tym, wiernym, którzy za radą M. Szyszkowskiego z dobrej woli, a nie z żadnego obowiązku będą chcieli tym sposobem obchodzić wspomniane siedem kościołów, autor przedkłada na kolejnych kartach broszury konkretne treści przeznaczone do kontemplacji. Ich przeznaczenie dla konkretnych kościołów stacyjnych sprawiło z kolei, że wierni, aby nie naruszać ich logicznego ciągu, musieli obrać drogę zgodną $\mathrm{z}$ chronologią zaproponowanych przez biskupa medytacji. W takim przypadku krakowski szlak siedmiu kościołów wyglądał następująco: pierwszą świątynią stacyjną był kościół farny NMP, skąd pątnicy winni się udać do konwentu dominikanów. Kolejno mieli podążać ulicą Grodzką, aż do kościoła świętych Piotra i Pawła, po którego nawiedzeniu udawali się do klasztoru oo. bernardynów na Stradomiu. Kolejnym kościołem stacyjnym była katedra wawelska, skąd wierni winni się udać do konwentu franciszkanów, a następnie do kolegiaty akademickiej św. Anny, gdzie peregrynacja dobiegała końca.

W pierwszym kościele stacyjnym, a więc w kościele NMP, biskup zalecił rozważanie tajemnic związanych $\mathrm{z}$ obecnością Maryi w wydarzeniach śmierci

${ }^{49}$ G. Severano, Divotioni da prattica..., dz. cyt., s. 12-23. Zgodnie z zaleceniami tego przewodnika-modlitewnika wierni winni rozważać tajemnice Męki Pańskiej w trakcie peregrynacji pomiędzy poszczególnymi kościołami stacyjnymi. Droga Chrystusa z Wieczernika do Ogrodu Oliwnego winna być rozważana podczas pierwszego przejścia między świątyniami. Podczas drugiego - droga Chrystusa z Ogrodu Oliwnego do domu Annasza, a podczas trzeciego - z domu Annasza do domu Kajfasza. Pomiędzy trzecim a czwartym kościołem wierni winni rozważać tajemnicę drogi Chrystusa z domu Kajfasza do Piłata, a pomiędzy czwartym i piątym drogę od Piłata do pałacu Heroda. Szóste przejście między świątyniami stacyjnymi miało ukierunkować wiernych na rozważanie drogi, jaką Chrystus pokonał, idąc z pałacu Heroda do Piłata, a siódme tajemnicę drogi na Kalwarię.

${ }^{50}$ Siedm kościołów krakowskich..., k. B5r.

${ }^{51}$ Siedm kościołów krakowskich..., k. B5r. 
i zmartwychwstania Chrystusa ${ }^{52}$. Kierujący się wskazówkami hierarchy wierni winni rozmyślać „rozstanie Pana Zbawiciela naszego na mękę odchodzącego z Matką swą miłą” oraz „z nią wespół mękę Syna iey opłakiwać”. W trakcie tej modlitewnej kontemplacji podążający krakowskimi ulicami pątnicy winni prosić o łaskę i pomoc, aby drogę siedmiu kościołów przejść $\mathrm{z}$ „nabożeństwem [...], słodkością ducha y doskonałością [...] jakoby dusza twoia, iako naylepiey do otrzymania Odpustów tych przygotować się i one otrzymać mogła"53.

Drugim kościołem stacyjnym był konwent dominikanów pw. Świętej Trójcy. Wierni winni rozważać w nim „Pana Zbawiciela naszego modlitwę w Ogroycu, ckliwość, lękanie, smętek, pot krwawy na wolę Oyca swego oddanie, a na koniec poimanie iego" ${ }^{4}$. Z kościoła dominikanów wiernym zalecano przejście do jezuickiej świątyni śś. Piotra i Pawła, gdzie winni rozważać „Zbawiciela naszego do Annasza y do Kaiphasza przyprowadzenie" oraz trzykrotne zaparcie się Piotra „y miłosierne obrócenie oczu Pańskich ku Piotrowi y iego nawrócenie" 55 . Czwartym kościołem stacyjnym - zgodnie z zaproponowaną przez Szyszkowskiego trasą peregrynacji - był konwent oo. bernardynów na Stradomiu. Wierni winni pochylić się tutaj nad wydarzeniem, kiedy „Zbawiciela naszego [dotknęło] wielkie od Heroda obelżenie, gdy za głupiego, ten który był wieczną Mądrością Oyca Swego, [...], stał się pośmiewiskiem nie tylko dworu Herodowego, ale y takiey wielkości ludu Onego niewiernego". Ponadto biskup zalecał, aby pielgrzymi po zakończeniu kontemplacji, prosili w swoich modlitwach, , aby nam przez one naśmiewiska y pokorę swoyą przebaczyć raczył wszystkie grzechy nasze, którycheśmy się przez niezbędną pychę naszą dopuścili” oraz „iżeby nas przyoblokł w szatę sumienia czystego, abyśmy nie tylko od winy wieczney grzechow śmiertelnych, ale też y od karania doczesnego, przez te Odpusty wolnymi zostając, oczom iego iako nabarziey podobać się mogli”'56.

Z kościoła św. Bernardyna wierni zobowiązani byli udać się do katedry wawelskiej. Zaproponowane przez Marcina Szyszkowskiego rozważania dla tego kościoła stacyjnego dotyczyły wydarzeń, kiedy Chrystus „u pręgierza przy obecności ludu niezliczonego obnażony, sromotnie, iako złoczyńca iaki, rózgami i biczami rozmaicie był sieczony y katowany”, a także „ostrą cierniową koroną dręczony, a nakoniec na śmierć bezecną y okrutną krzyżową niewinnie od Piłata wskazany

\footnotetext{
${ }^{52}$ Siedm kościołów krakowskich..., k. B6r.

${ }^{53}$ Siedm kościołów krakowskich..., k. B6v-B7r.

${ }^{54}$ Siedm kościołów krakowskich..., k. B7r-v.

${ }^{55}$ Siedm kościołów krakowskich..., k. B7v-B8r.

${ }^{56}$ Siedm kościołów krakowskich..., k. B8r-v.
} 
y potępiony" ${ }^{57}$. W szóstym kościele stacyjnym, czyli konwencie franciszkanów konwentualnych wierni mieli z kolei kontemplować wydarzenia, podczas których „Zbawiciel nasz na szubienicy krzyżowey dla zbawienia ludzkiego, ostremi gwoździami srogo rozpięty, Krew swą drogą obficie za grzechy nasze wylewaiąc y w onych tak cięszkich boleściach przez trzy godziny wisząc, na każdego z nas z osobna pomniał”. W nawiązaniu do wspomnianych treści rozważań, wierni mieli modlić się, aby „rozgrzał y rozpalił y zmiękczył oziębłe a zatwardziałe serca nasze ogniem Ducha Świętego y aby od nas oddalił serce kamienne, a dał nam serce ludzkie [...], żebyśmy się od grzechów przyszłych iuż nie bojaźnią piekła, ani inszego karania, ale samą miłością iego tak wielką hamowali" ${ }^{38}$.

Z kościoła św. Franciszka droga krakowskich pątników wiodła do ostatniego - siódmego - kościoła stacyjnego, którym była kolegiata akademicka św. Anny. Wierni winni rozważyć tutaj wydarzenia związane ze zdjęciem Chrystusa z krzyża i „łzami przesmutnej Matki swey oblany, maściami namaszczony [i] w prześcieradła pogrzebne obwiniony". Ponadto biskup Szyszkowski zalecał, aby w tym kościele, po zakończeniu kontemplacji wspomnianych wyżej wydarzeń, wierni prosili w swoich modlitwach, aby „przez ono wielkie poniżenie swoie [...] uchował duszę twą y od ciemnych onych podziemnych tarasów y dał ci łaskę [...] iakobyś bez żadney przeszkody [...] mógł wolności Synów Bożych, to iest wiernych wybranych iego, tak na tym, iako y na drugim świecie zawżdy zażywać y z niey się cieszyć" "59. Kończąc obchodzenie siedmiu kościołów miasta Krakowa, hierarcha zobowiązał postępujących za jego wskazaniami wiernych, aby tak, jak na początku drogi, tak i na jej końcu wezwali wstawiennictwa Najświętszej Maryi Panny i prosili ją, aby „ona to małe pielgrzymstwo twoje [...] Synowi swemu na cześć męki iego, a otrzymanie doskonalszego odpuszczenia grzechów twoich ofiarowała [...], tak żebyś tych odpustów [...] jako nadoskonaley dostąpiwszy y od win grzechowych wolnym zostawszy, oczom iego iako naylepi się podobać mógł"60.

Mimo iż omawiane nabożeństwo dotyczyło nawiedzenia siedmiu kościołów miasta Krakowa, jego pomysłodawca zachęcał pielgrzymów do wstąpienia w progi jeszcze dwóch innych świątyń, które leżały na trasie peregrynacji. Mowa tutaj o jezuickim kościele pod wezwaniem św. Barbary oraz świątyni karmelitów poświęconej św. Michałowi Archaniołowi. W pierwszym z nich, który wierni

\footnotetext{
${ }^{57}$ Siedm kościołów krakowskich..., k. B8v-Cir.

${ }^{58}$ Siedm kościołów krakowskich..., k. Cir-v.

${ }^{59}$ Siedm kościołów krakowskich..., k. C2r-v.

${ }^{60}$ Siedm kościołów krakowskich..., k. C2v-C3r.
} 
mijali idąc z kościoła farnego do konwentu dominikanów, biskup zalecał rozważanie tajemnicy ustanowienia Eucharystii, w drugim natomiast, który leżał na trasie wiodącej $z$ katedry wawelskiej do kościoła franciszkanów, pątnicy winni kontemplować wydarzenia związane $\mathrm{z}$ niesieniem krzyża ${ }^{61}$. Ponadto z zaleceń, które zostały ogłoszone na kazaniu w kościele świętych Piotra i Pawła w dniu inauguracji nabożeństwa, wierni dowiedzieli się, iż w pierwszym ze wspomnianych powyżej kościołów mieli dziękować za dar Eucharystii i prosić o łaskę, aby „tak godnie y często tego wielkiego Sakramentu pożywać, jakobyśmy nim posileni y zmocnieni, mężnie wszytkie przeszkody, które na tym świecie do otrzymania królestwa niebieskiego mamy, przezwyciężywszy, tam się dostali” ${ }^{2}$. Z kolei w kościele klasztornym św. Michała pielgrzymi mieli prosić w swoich modlitwach, aby żaden $\mathrm{z}$ nich „nie był w liczbie nieprzyjaciół krzyża [...] ale żeby cię [Chrystus] uczynił iednym $\mathrm{z}$ tych, którzy złym namiętnościom y skłonnościom swym mocno się sprzeciwiają y krzyż swoy zmartwienia niosąc, za nim tak strapionym idą" ${ }^{63}$.

Można zatem zauważyć, iż peregrynacja w dwóch przywołanych powyżej świątyniach została zorganizowana przez biskupa Szyszkowskiego na zasadach podobnych do tych, jakie obowiązywały wiernych w pozostałych siedmiu kościołach. Różnica polegała jedynie na tym, iż zalecane przez hierarchę modlitwy i rozważania mieli oni odprawiać przed ołtarzem głównym oraz trzema dowolnie wybranymi ołtarzami bocznymi - w przypadku kościoła św. Barbary ${ }^{64}$ oraz najprawdopodobniej tylko przy ołtarzu głównym, jeżeli chodzi o kościół karmelitów. Wydawca broszury nie precyzuje bowiem w trakcie opisu drugiego ze wspomnianych kościołów, przed jakimi dokładnie ołtarzami pielgrzymi winni odprawiać nabożeństwo ${ }^{65}$.

\section{Zakończenie}

Podsumowując należy stwierdzić, iż przedstawiony powyżej krakowski szlak "le sette chiese di Roma” został stworzony przez biskupa krakowskiego Marcina Szyszkowskiego na przełomie 1620 i 1621 roku. Wytyczając w Krakowie szlak

\footnotetext{
${ }^{61}$ Siedm kościołów krakowskich..., k. C3r-v.

${ }^{62}$ Siedm kościołów krakowskich..., k. C5r.

${ }^{63}$ Siedm kościołów krakowskich..., k. C6r.

${ }^{64}$ Siedm kościołów krakowskich..., k. C5v.

${ }^{65}$ Siedm kościołów krakowskich..., k. C6r.
} 
siedmiu kościołów rzymskich, biskup ten realizował nie tylko zalecenia duszpasterskie oparte na reformie trydenckiej, ale także związany z duchem tego soboru wzorzec biskupa dobrego pasterza. Naśladował w tym m.in. twórcę nabożeństwa siedmiu kościołów rzymskich - św. Filipa Nereusza, ale także św. Karola Boromeusza. Wspomniane postacie bezsprzecznie wywarły ogromny wpływ na przebywającego w końcu Xvi wieku w Rzymie ówczesnego kanonika krakowskiego. Już jako biskup wprowadzał w życie zasady duszpasterstwa, których uczył się od wyżej wspomnianych kapłanów. Doskonałym tego przykładem było chociażby przeszczepienie na grunt krakowski tzw. nabożeństwa siedmiu kościołów rzymskich. Wyrastająca $z$ antycznej tradycji peregrynacja zajaśniała wówczas nowym blaskiem nie tylko w Rzymie, ale także w potrydenckim Krakowie.

\section{Streszczenie}

Przypuszcza się, iż opisany w Xvi wieku przez św. Filipa Nereusza szlak wędrówki dewocyjnej po siedmiu bazylikach Rzymu mógł mieć swoje źródła w tradycji ludowej, a bez wątpienia wynikał z przywołania i zaadaptowania do nowych warunków pamięci o znanej niegdyś ludycznej w charakterze obrzędowości modlitewnej. Opisane przez tego świętego itinerarium pielgrzymie wyznaczały cztery bazyliki większe: św. Piotra na Watykanie, św. Pawła za Murami, św. Jana na Lateranie, Najświętszej Maryi Panny Śnieżnej oraz trzy mniejsze: św. Krzyża Jerozolimskiego, św. Wawrzyńca za Murami oraz św. Sebastiana.

W 1621 roku w krakowskiej oficynie drukarskiej Franciszka Cezarego została wydana broszura zatytułowana Siedm kościołów krakowskich. Inicjatorem jej druku był biskup krakowski Marcin Szyszkowski, który przez wiele lat przebywał w Rzymie, gdzie zapoznał się z działalnością św. Filipa Nereusza. Od chwili, kiedy został biskupem krakowskim zaczął zaszczepiać w swojej diecezji elementy potrydenckiej dewocji Wiecznego Miasta. Jednym z nich było zainicjowanie nabożeństwa Siedmiu kościołów krakowskich, które otrzymało przywileje i odpusty rzymskiego szlaku pątniczego.

Słowa kluczowe

Marcin Szyszkowski, Rzym, Kraków, pobożność, „Siedem kościołów” 


\section{Abstract \\ Bishop Marcin Szyszkowski (1616-1630) as the creator of the Service of Seven Krakow Churches}

The religious tour of seven Roman basilicas described back in the 16th century by St Philip Neri is thought to have its roots in folk tradition, though undoubtedly was a product of recalling and adapting the memory of an old, ludic prayer tradition to the new circumstances. The itinerary described by the saint listed four major basilicas: St Peter's Basilica in Vatican, St Paul's Basilica Outside the Walls, Basilica of St John Lateran, Basilica of St Mary and three minor ones: Basilica of the Cross of Jerusalem, St Basilica of St Lawrence Outside the Walls, and St Sebastian's Basilica.

In 1621 the Krakow printing house of Franciszek Cezary issued a brochure entitled Siedm kościołów krakowskich. Its release was initiated by Marcin Szyszkowski, who had stayed in Rome for many years, where he acquainted himself with the work of St Philip Neri. The moment Szyszkowski became the Krakow bishop, he began to implement elements of post-Trent devotion of the Eternal City in his own diocese. One of such innovations was to initiate the Service of the Seven Krakow Churches, which was granted privileges and indulgences of the Roman pilgrimage trail.

Keywords

Marcin Szyszkowski, Rome, Krakow, piety, „Seven Krakow Churches”

\section{Bibliografia}

\section{Źródła}

Archiwum Krakowskiej Kurii Metropolitalnej, A.Ep. 43, k. 608v-609.

Instructio ad visitandas Septem Ecclesia Cracoviae [...], [w:] Reformationes Generales [...], Cracovia 1621.

Instructio ad Visitandas Septem Ecclesias Cracoviae [...], Cracovia 1620.

Pruszcz P. H., Kleynoty Stołecznego Miasta Krakowa [...], Kraków 1650.

Pruszcz P. H., Kleynoty Stołecznego Miasta Krakowa [...], Kraków 1745.

Severano G., Divotioni da prattica nelle visita delle sette Chiese di Roma, Roma 1654.

Severano G., Memorie sacre delle sette chiese di Roma e di altri luoghi, che si trovano per le strade di esse, Roma 1630.

Siedm kościołów krakowskich. Od Stolice Apostolskiey pozwoleniem Odpustów Siedmi Kościołów Miasta Rzymskiego uprzywilejowanych [...], Kraków 1621. 


\section{Opracowania}

Bania Z., Kraków - Rzymem Rzeczypospolitej w pierwszej połowie xvII wieku, [w:] Praxis atque theoria. Studia ofiarowane profesorowi Adamowi Małkiewiczowi, red. W. Bałus, J. K. Ostrowski, Kraków 2006, s. 25-33.

Barock im Vatikan. Kunst und Kultur im Rom der Päpste, Bd. 2: 1572-1676, Hrsg. J. Frings, Leipzig 2005.

Bernabei R., Roma nel giubileo, Milano 1998.

Chélini J., Branthomme H., Drogi Boże. Historia pielgrzymek chrześcijańskich, Warszawa 1996.

Delcroix R., Filippo Neri. Il Santo dell'allegria, Milano 2011.

Eiche S., Le Basiliche e il loro doppio: le sei tavole di Augsburg, [w:] Roma Sancta. La città delle basiliche, a cura di M. Fagiolo, M. L. Madonna, Roma 1985, s. 47-51.

Fiorani L., Le confraternite, la città e la „perdonanza giubilare”, [w:] Roma Sancta. La città delle basiliche, a cura di M. Fagiolo, M. L. Madonna, Roma 1985, s. 54-70.

Gamrath H., Roma Sancta Renovata. Studi sullurbanistica di Roma nella seconda metà del sec. XVI con particolare riferimento al pontificato di Sisto V (1585-159o), Roma 1987.

Garms J., Vedute di Roma. Dal Medioevo all'Ottocento. Atlante iconografico, topografico, architettonico, vol. 1-2, Napoli 1995.

Goldberg G., Zum Zyklus de Augsburger Basilikabilder und zur Existenz von Stellvertreterstätten römische Hauptkirchen, „Bayerisches Jarbuch für Volkskunde“1986/87, s. 65-75.

Hülsen C., Das Speculum Romanae Magnificentiae des Antonio Lafreri, [w:] Colloctanaea variae doctrinae, München 1921, s. 121-170.

Jung-Inglessis E. M., Rok Święty w Rzymie. Historia i teraźniejszość, Warszawa 2000.

Kalinowska J., Mysterium Septiformis Ecclesaie, „Annalecta Cracoviensia” 23 (1991), s. 307-323.

Kracik J., Powszechny, apostolski, w historię wpisany, Kraków 2005.

Krasnowolski B., Zapomniane sanktuarium maryjne i lateraneńskie z I poł. XVII wieku w Suchej: wielka treść w skromnej formie, [w:] Festina lente. Prace ofiarowane Andrzejowi Fischingerowi w siedemdziesiąta rocznicę urodzin, red. M. Piwocka, D. Nowacki, Kraków 1998, s. 127-138.

Kwapis O., Do Rzymu. Sztuka i wielkie jubileusze (1300-1575), Warszawa 2014.

Monselice nel cuore del Giubileo. Guida del pellegrino al Santuario Giubilare delle sette Chiese in Monselice, Monselice 1999.

Pawłowska B., Urbs Sacra. Pielgrzymki i podróże religijne do Rzymu w starożytności chrześcijańskiej (IV-VII w.), Kraków 2007.

Prosperi Valenti Rodinò S., L'immagine degli anni santi nelle stampe, [w:] La storia dei Giubilei, vol. 2: 1450-1575, a cura di M. Fagiolo, M. L. Madonna, Milano 1998, s. 282-293. Rinaldi A., Le sette meraviglie della Roma cristiana. L'invenzione del Lafréry, [w:] Roma Sancta. La città delle basiliche, a cura di M. Fagiolo, M. L. Madonna, Roma 1985, s. 269-274. 
Schawe D., Rom in Augsburg. Die Basilikabilder aus dem Katharinenkloster, München 2000. Smolucha J., Sroka S. A., Historia lat świętych, Kraków 2000.

Stróż A., Historia badań nad zagadnieniem najstarszych zachodnich sanktuariów męczenników. Od kontrreformacyjnej apologetyki do współczesnych badań interdyscyplinarnych, „Vox Patrum” 33 (2013), s. 315-334.

Vazzoler M., Il giubileo di San Carlo Borromeo (Milano, 1576), Milano 1999.

Wróbel E. E., Życie religijne i zakonne w Polsce na przełomie XVI i XVII wieku, [w:] Cztery wieki Karmelitów Bosych w Polsce (1605-2005), red. A. Ruszała, Kraków 2005, s. 1-19.

Zeitler K., Wege durch Rom. Druckgraphische Veduten aus drei Jahrhunderten, München 1999. 